Yüzüncü Yil Üniversitesi
Tarim Bilimleri Dergisi

Araştırma Makalesi (Research Article)

Spatial and Seasonal Price Variations of Fresh Tomato: Evidence from Nigeria

\author{
Achoja Felix ODEMERO**, ${ }^{*}$ Theophilus Miebi GBIGBI ${ }^{2}$ \\ ${ }^{1}$ Department of Agricultural Economics and Extension \\ ${ }^{2}$ Delta State University Asaba Campus, Asaba, Nigeria \\ *Corresponding author's E-mail:lixmero40@yahoo.com \\ Co-author’s e-mail:gbigbitheophilusmiebi@yahoo.com
}

\section{Article Info}

Recieved: 28.09.2018

Accepted: 29.03.2019

Online Published 28.06.2019

DOI: $10.29133 /$ yyutbd.464931

\section{Keywords}

Consumer welfare,

Tomato market,

Price variation,

Seasonal,

Spatial

\begin{abstract}
The degree of price variation of fresh tomato over space and time; and its effect on consumer welfare is not yet known in Nigeria. This study therefore examined the effect of spatial and seasonal price variations of fresh tomato marketing on the welfare of consumers in Nigeria. Primary data were collected with structured questionnaire from 240 randomly selected tomato marketers. The data were analyzed using descriptive and inferential statistical tools. Finding showed that the mean price of fresh tomato per basket was $\$ 16,350$ for minor markets and $\$ 12,450$ for major markets. Test of hypothesis indicated a significant $(p<0.05)$ spatial price variation. Further result indicated a significant $(p<0.05)$ inter-seasonal price variation with a mean of $\$ 18,000 /$ basket for off season and $\$ 6,400 /$ basket for peak season. The result revealed that seasonal price variation (64.4\%) is higher than spatial price variation $(23.9 \%)$ in Nigeria. Regression result and factor analysis indicated that duration of product in store before sale, bargaining power of seller, patronage, packaging charges and transportation cost were the most significant determinant of fresh tomato price variation which affect the welfare of tomato consumers. Price variation exerts negative and significant $(p<0.05)$ effect on consumers welfare through higher expenditure on consumption and low level of patronage (demand). We recommended that government should improve the rural road network to reduce transportation cost and spoilage of fresh tomato in Nigeria.
\end{abstract}

\title{
Taze Domatesin Mekansal ve Mevsimsel Fiyat Varyasyonları: Nijerya Örneği
}

\section{Makale Bilgileri}

Geliş: 28.09.2018

Kabul: 29.03.2019

Online Yayinlanma 28.06.2019

DOI: $10.29133 /$ yyutbd.464931

\author{
Anahtar Kelimeler \\ Tüketici refahı, \\ Domates pazarı, \\ Fiyat değișimi, \\ Mevsimsel, \\ Mekansal
}

Öz: Taze domateslerin mekan ve zaman içindeki fiyat değişimlerinin derecesi; ve Nijerya'da tüketici refahı üzerindeki etkisi henüz bilinmemektedir. Bu nedenle, bu çalışma, taze domates pazarlamasının mekansal ve mevsimsel fiyat değişimlerinin, Nijerya'daki tüketicilerin refahı üzerindeki etkisini incelemiştir. Birincil veriler, rastgele seçilmiş 240 domates satıcısından yapılandırılmış anket ile toplanmıştır. Veriler, tanımlayıcı ve çıkarımsal istatistiksel araçlar kullanılarak analiz edilmiștir. Bulgu, sepet başına taze domates fiyatının küçük pazarlar için 16,350 —ve büyük pazarlar için 12,450 olduğunu göstermiştir. Hipotez testi, anlamlı $(\mathrm{p}<0.05)$ bir mekansal fiyat değişimini göstermiştir. Diğer sonuçlar, sezon dişı sezon için fiyat farkı, sezon dışı sezon için ortalama $18.000 \AA$ / sepet ve yoğun sezon için 6.400 / sepet olmak üzere önemli bir değişiklik göstermiştir. Sonuç olarak, Nijerya'da mevsimsel fiyat değişiminin (\% 64.4) mekansal fiyat değişkeninden (\% 23.9) daha yüksek olduğunu ortaya koymuştur. Regresyon sonucu ve faktör analizi, satış öncesi mağazadaki ürünün süresinin, satıcının pazarlık gücünün, patronajın, paketleme ücretlerinin ve nakliye maliyetinin, domates tüketicilerinin refahını etkileyen taze domates fiyatlarındaki 
en önemli belirleyici faktör olduğunu göstermiştir. Fiyat değişimi, tüketim harcamalarının artması ve düşük hamle seviyesi (talep) yoluyla tüketicilerin refahı üzerinde olumsuz ve önemli $(p<0.05)$ bir etkiye sahiptir. Nijerya'da nakliye maliyetini ve taze domates bozulmasını azaltmak için hükümetin kırsal yol ağını iyileştirmesi tavsiye edilebilir.

\section{Introduction}

Tomato is important in the daily meal of households in most parts of the world. It is an essential ingredient in soups or sometimes consumed raw as juice and sauces, ketchups, purees and pastes. It is an important raw material in the canning industries. The unriped tomato is used for prickles (Haruna et al., 2012). Tomato marketing in domestic markets is a source of livelihood to those who engaged in it and can generate foreign exchange earnings to exporting nations.

Nigeria is ranked second largest producer of tomato in Africa and 16th largest tomato producing nation in the world and has the comparative advantage and potential to lead the world in tomato production and exports (FAO, 2010). The production of tomato in Nigeria in 2010 was about 1.8 million metric tonnes (FAO, 2010). The demand for tomato and its by-products far outweighs the supply. The marketing of fresh tomato is characterized by the problems of seasonality and perishability. This tends to encourage price distortion and inefficiency in the marketing of tomato (Obayelu and Alimi, 2013).

Spatial price analysis is the smooth transmission of price signals and information across spatially separated markets (Ghaforr et al., 2009). Fresh tomato price contributes significantly to the pace and direction of development in tomato industry. They serve as market signals to the relative scarcity or abundance of tomato (Akintunde et al., 2012). Prices of fresh tomato vary from month to month and even from day to day (Olukosi et al., 2007). Similar observation was made by Sani and Hossein (2011) in Iran.

Offseason production of tomato can take advantage of higher prices. Producers of tomato can benefit the most if they can manage to offset the costs or expenses incurred, which are usually higher than the ones generally incurred during the regular season, with higher sales prices (Shepherd and Ilboudo 2010). The transportation of fresh tomato from one market to another is costly and requires special efforts. Transfer cost that consists of the cost of transferring fresh tomato from one market to another is an important variable in spatial price analysis (Sundar and Darren, 2003).

The spatial price analysis of fresh tomato is one of the important areas to study the structure of fresh tomato markets and how they performed (Ghafoor et al., 2009). The need for spatial price analysis arises because agricultural commodities like fresh tomato are bulky, their production is seasonal, and their production and consumption points are spatially dispersed. The spatial and seasonal price variation of fresh tomato has not received adequate study by various workers in Nigeria. The prevailing marketing system of fresh tomato in Nigeria suffers from a number of imperfection and problems such as characteristics associated with the nature of tomatoes which resulted to imperfection in its marketing system and also having adverse effect on market price (Okpeke, 2015).

The degree of price variation of fresh tomato over space and time; and its effect on consumer welfare is not yet known in Nigeria. Fluctuation in price of tomato and the possible factors that influence the spatial price variation of fresh tomato deserve thorough investigation so as to improve its production and marketing system. This will improve the welfare of producers and consumers of fresh tomato in the area of study.

The present research was design to provide answers to the following research questions: what is the degree of spatial price variation of fresh tomato (i.e between major and minor markets) in the study area? What is the seasonal price differential of fresh tomato (i.e between peak season and off season) in the study area? What are the significant factors that influence price variation of fresh tomato What is the dimension and direction of effect of price variation on well being of consumers of fresh tomato in Nigeria? 


\section{The specific objectives of the research are to:}

i. determine price difference between major and minor fresh tomato markets;

ii. ascertain price difference between off-season and peak season fresh tomato marketing;

iii. identify the significant factors that influence price variation of fresh tomato; and

iv. examine the effect of price variation on welfare of fresh tomato consumers.

\section{Materials and Methods}

\subsection{Area of study}

The study was conducted in Delta State, Nigeria. The area was chosen for the study due to the fact that it has a favorable environment for the production and marketing of fresh tomato. Delta State is located in the region known as the Niger Delta, South-South geo-political zone with a population of 4,098,291 million and a total land area of 17,698 square kilometers (National Population Commission 2007). The State lies between Longitudes 50 and 6045 East and Latitudes 50 and 6030 North. It shares common boundaries with Edo State in the north, the east by Anambra State, Southeast by Bayelsa State and on the southern flank is the Bright of Benin which covers about $160 \mathrm{~km} 2$ of the states coastline (National Bureau of Statistics, State Information 2015). The area of study is characterized by two seasons, the rainy season which last from April-October, and the dry season from November to March. The annual temperature ranges between $27 \mathrm{oC}$ and $37 \mathrm{oC}$ which helps the yield of tomato. There are 25 Local Government Areas in the State which are grouped into three zones namely: Delta North Zone, Delta Central Zone and Delta South Zone. Major crops grown are yams, cassava, tomatoes, pepper, plantain, cocoyam, maize etc.

\subsection{Sampling Technique and Data Collection}

Primary data were used to generate information for the study. Primary data were obtained with the use of a well-structured questionnaire.

A multi-stage sampling technique was adopted in selecting respondents. In the first stage, two (2) local governments were randomly selected from each of the three (3) agricultural zones which total six (6) LGAs. The second stage involved the purposive selection of two (2) markets from the Local Government Areas selected to give a total of twelve (12) markets. This selection was based on the level of fresh tomato marketing activities in the markets. The selected markets were Orhuwhorun, Jigbale, Otokutun, Effurun, Hausa mkt, Igbudu, Ozoro, Patani, Igbodo, Garage mkt Agbor, Ugbolu and Ogbogonogo. The third stage was the random selection of twenty (20) fresh tomato marketers from each of the markets making a total of two hundred and forty (240) for the study.

\subsection{Method of Data Analysis}

Objectives were achieved with mean, t-test analysis and multiple regression.

\subsubsection{Model Specification}

The implicit form of the multiple regression models is specified as follow:

$Y=f\left(X_{1}, X_{2}, X_{3}, X_{4}, X_{5}, X_{6}, X_{7} \ldots \ldots X_{n}+e\right)$

Four functional forms of the multiple regression model, (linear, semi-log, exponential and double $\log$ ) was fitted to the data and the one with the best fit was chosen as the lead equation based on the economic, statistical and econometric criteria.

The explicit forms of the four functional equations are stated as follow:

Linear:

$\left.\mathrm{Y}=\mathrm{b}_{0}+\mathrm{b}_{1} \mathrm{X}_{1}+\mathrm{b}_{2} \mathrm{X}_{2}+\mathrm{b}_{3} \mathrm{X}_{3}+\mathrm{b}_{4} \mathrm{X}_{4}+\mathrm{b}_{5} \mathrm{X}_{5}+\mathrm{b}_{6} \mathrm{X}_{6}+\mathrm{b}_{7} \mathrm{X}_{7} \ldots \ldots . \mathrm{X}_{\mathrm{n}}+\mathrm{e}\right)$ 
Semi-log:

$\left.\mathrm{Y}=\mathrm{b}_{\mathrm{o}}+\mathrm{b}_{1} \log \mathrm{X}_{1}+\mathrm{b}_{2} \log \mathrm{X}_{2}+\mathrm{b}_{3} \log \mathrm{X}_{3}+\mathrm{b}_{4} \log \mathrm{X}_{4}+\mathrm{b}_{5} \log \mathrm{X}_{5}+\mathrm{b}_{6} \log \mathrm{X}_{6}+\mathrm{b}_{7} \log \mathrm{X}_{7} \ldots \ldots \mathrm{X}_{\mathrm{n}}+\mathrm{e}\right)$

Double log:

$\left.\log Y=b_{0}+b_{1} \log X_{1}+b_{2} \log X_{2}+b_{3} \log X_{3}+b_{4} \log X_{4}+b_{5} \log X_{5}+b_{6} \log X_{6}+b_{7} \log X_{7} \ldots \ldots . X_{n}+e\right)$

Exponential function:

Ln $\left.Y=b_{0}+b_{1} X_{1}+b_{2} X_{2}+b_{3} X_{3}+b_{4} X_{4}+b_{5} X_{5}+b_{6} X_{6}+b_{7} X_{7} \ldots \ldots X_{n}+e\right)$

Where ;

$Y=$ price variation (\%); $X_{1}=$ Transportation $\operatorname{cost}(\AA) ; X_{2}=\operatorname{distance}(\mathrm{km}) ; X_{3}=\operatorname{storage} \operatorname{cost}(\#) ; X_{4}=$ homogeneity of product(dummy; $1=y e s$, otherwise $=0) ; X_{5}=$ market levies( $\left.¥\right)$

$\mathrm{X}_{6}=$ union interference(dummy; $1=$ yes, otherwise $=0$ ); $\mathrm{X}_{7}=$ packaging charges( $(\mathbb{N})$;

$\mathrm{X}_{8=}$ bargaining power of buyers(very strong $=4$, strong $=3$, weak=2, very weak $=1$ );

$\mathrm{X}_{9}=$ bargaining power of suppliers(very strong $=4$, strong $=3$, weak=2, very weak=1);

$\mathrm{X}_{10}=$ patronage rate(quantity purchase); $\mathrm{X}_{11}=$ duration of product in store before sale(days); $\mathrm{b}_{1}-\mathrm{b}_{11}=$ coefficients of explanatory variables; $\mathrm{e}_{\mathrm{i}}=$ error term .

\section{Results}

\subsection{Price Difference between Major and Minor Markets}

Table 1shows that, in the major markets, Ogbogonogo had highest market price for fresh tomato of 14750. However, Hausa market had the least price of 10400 . Spatially, Effurun market had $\$ 12500$, Igbudu market had $\$ 12150$, Garage market Agbor had $\$ 12900$ and Orhuwhorun market \$12000. Table 1 showed the high variation in price of fresh tomato in the major market ranging from \$10400 to \$14750. Spatially, Igbodo market in the minor markets had the highest market price for fresh tomato of $\$ 20000$. However, Otokutun had the least price per basket of fresh tomato at $\$ 12600$. The result further indicated high variation in price of fresh tomato among the minor markets in the study area ranging from $\$ 20000$ to $\$ 12600$. The variation of prices in the major and minor markets may be attributed to distance, cost of transportation (transfer cost), levies, union dues and demand/supply factors. The result shows that the bargaining power of buyers and suppliers create a price difference among major markets.

Table 1: Price Variation of Fresh Tomato between Major and Minor Markets ( Field data, 2016).

\begin{tabular}{llll}
\hline Major markets & Price (\#) & Minor markets & Price (\#) \\
\hline Effurun & 12500 & Jigbale & 14000 \\
Hausa market & 10400 & Otokutun & 12600 \\
Igbudu & 12150 & Ozoro & 16000 \\
Garage market Agbor & 12900 & Patani & 18500 \\
Ogbogonogo & 14750 & Igbodo & 20000 \\
Orhuwhorun & 12000 & Ugbolu & 17000 \\
Mean & $\mathrm{N} 12,450$ & & $\mathrm{~N} 16,350$ \\
Coefficient of variation $(\mathrm{CV})$ & $16 \%$ & & $35 \%$ \\
\hline
\end{tabular}




\subsection{Hypothesis Testing.}

Ho1: There is no significant price variation between major and minor fresh tomato markets.

To ascertain if there is significant spatial price variation of fresh tomato between major and minor markets a t- test analysis was conducted (Table 2). The result of the t-test supports the assertion that there is significant difference between prices of fresh tomato in major and minor markets. This was because the mean t-test score of minor market $\$ 16350$ was more than the mean t-test score of major market $\$ 12450$. The result showed a t-value of -5.5953 . This was significant at $5 \%$ probability level.

Table 2: T-Test Analysis of Price Difference between Major and Minor Markets (Field data, 2016).

\begin{tabular}{llllll}
\hline Markets & Mean( $(\mathbb{*})$ & Std Deviation & Std Error Mean & t.cal & Pr>t \\
& & & & & \\
\hline Major mkt price & 12,450 & 1413.506 & 577.0615 & -5.5953 & 0.0025 \\
& & & & & \\
\hline Minor mkt price & 16,350 & 2759.529 & 1126.573 & & \\
& & & & & \\
\hline
\end{tabular}

\subsection{Determinants of Price Variation of Fresh Tomato}

The result in Table 5 showed the estimated regression result of the factors influencing spatial price variation of fresh tomato marketers in the study area. The double log functional form was chosen as the lead equation on the basis of $\mathrm{R}^{2}$ value of $76 \%$ and number of significant exogenous variables in the model. The coefficient of multiple determination for the fresh tomato marketers $\left(\mathrm{R}^{2}=0.7612\right)$ was significant at $1 \%$ probability level. This implies $76 \%$ of variation in output of fresh tomato marketers was accounted for by the variables considered in the study. The remaining $24 \%$ of spatial price variation of fresh tomato marketers could be due to factors not investigated in the study.

\subsection{Transportation Cost}

The coefficient of transportation cost was positive and highly significant at $1 \%$ probability level. This implies that $1 \%$ increase in transportation cost (0.1065) of fresh tomato marketing will lead to $10.7 \%$ increase in spatial price variation among the fresh tomato marketers in the study area.

\subsection{Distance}

The coefficient of distance (0.1877) was positive and significant at $5 \%$ level of probability, implying that the longer the distance from one market to the others, the more the price variation that will be created.

\subsection{Storage Cost}

The coefficient of storage cost (0.0975) was positively and statistically significant at $5 \%$ probability level. This implies that storage cost is directly related to price variation. The increase in price of tomato is normally affected by the consumer who bears the consequence to enable the sellers maximize profit.

\subsection{Market levies}

The coefficient of market levies (0.0913) was positive and significant at 5\% probability level which implies that increase in market levies will increase price variation. Packaging cost

The coefficient of packaging (0.0890) was positive and significant at $1 \%$ probability level which implies that any increase in packaging charges will lead to increase in price variation.). 


\subsection{Bargaining power of supplier}

The coefficient of bargaining power of supplier (0.6346) was positive and significant at $1 \%$ probability level which implies that any increase in bargaining power of supplier will lead to increase in price variation. Bargaining power of supplier refers to the power of suppliers to influence the setting of prices of tomato whether they have or not when the market is imperfect. The bargaining power was expected to increase the probability of selling to ready buyers. Bargaining power of middlemen could influence producers because of the perishable nature of tomato where there is risk of loss with delays in exchange of fresh tomatoe. Marketers with good bargaining power prefer a more individualistic business strategy. i.e selling to rural markets.

\subsection{Patronage}

The coefficient of patronage (-1.0700) was negative and significant at $1 \%$ probability level which implies that any increase in price will lead to decrease in quantity of fresh tomato purchased and consumed.

\subsection{Duration of product in store before sale}

The coefficient of duration (-1.0444) was negative and highly significant at $1 \%$ probability level which implies that any increase in duration of the product at the store before sale will lead to decrease in price of fresh tomato. The longer the fresh tomato stays for days before selling at the market will affect the selling price at which the consumer will be willing to purchase the product since the quality of the fresh tomato might have been deteriorated resulting to price variation within and between markets. The consumer might not have maximum satisfaction to buy more of the product to avoid spoilage.

Table 5: Determinants of Price Variation on Fresh Tomato Marketing Source (Field data, 2016)

\begin{tabular}{|c|c|c|c|c|}
\hline Variable & Linear & Semi-log & Double-log & Exponential \\
\hline \multirow[t]{2}{*}{ Transportation cost } & 1.6518 & 12411.87 & 0.1065 & 0.0000 \\
\hline & $(8.53)^{* * *}$ & $(3.76)^{* * *}$ & $(2.95)^{* * *}$ & $(5.70)^{* * *}$ \\
\hline \multirow[t]{2}{*}{ Distance } & 316.6213 & 11728.42 & 0.1877 & 0.0025 \\
\hline & $(1.20)$ & $(1.66)$ & $(2.42)^{* *}$ & $(2.14)^{* *}$ \\
\hline \multirow[t]{2}{*}{ Storage cost } & 0.0232 & 9076.814 & 0.0975 & $4.36 \mathrm{e}-07$ \\
\hline & $(0.50)$ & $(2.61)^{* *}$ & $(2.56)^{* *}$ & $(0.91)$ \\
\hline \multirow[t]{2}{*}{ Homogeneity of product } & 2839.242 & 913.7049 & 0.0101 & 0.0436 \\
\hline & $(0.52)$ & $(0.67)$ & $(0.68)$ & $(0.78)$ \\
\hline \multirow[t]{2}{*}{ Market levies } & 0.0916 & 6404.496 & 0.0913 & $1.82 \mathrm{e}-06$ \\
\hline & $(0.79)$ & $(2.10)^{* *}$ & $(2.73)^{* *}$ & $(1.52)$ \\
\hline \multirow[t]{2}{*}{ Union interference } & -3950.342 & -1126.784 & -0.0051 & -0.0109 \\
\hline & $(-0.82)$ & $(-0.94)$ & $(-0.39)$ & $(-0.22)$ \\
\hline \multirow[t]{2}{*}{ Packaging charges } & 0.0660 & 2472.852 & 0.0890 & $-5.35 e-07$ \\
\hline & $(0.18)$ & $(0.57)$ & $(5.34)^{* * *}$ & $(-0.14)$ \\
\hline Bargaining power of buyer & 15873.01 & -912.7903 & -0.0379 & 0.4431 \\
\hline Bargaining power of supplier & $(3.92)^{* * *}$ & $(-0.12)$ & $(-0.44)$ & $(10.66)$ \\
\hline \multirow[t]{2}{*}{ Patronage } & -7623.608 & 2820.702 & 0.6346 & 0.0289 \\
\hline & $(-2.39)^{* *}$ & $(0.45)$ & $(9.27)^{* * *}$ & $(0.88)$ \\
\hline \multirow[t]{4}{*}{ Duration } & -18030.23 & -52963.49 & -1.0700 & -0.1276 \\
\hline & $(2.03)^{* *}$ & $(4.75)^{* * *}$ & $(8.74)^{* * *}$ & $(1.40)$ \\
\hline & -21049.26 & -70370.4 & -1.0444 & -0.3787 \\
\hline & $(-6.45)^{* * *}$ & $(-11.15)^{* * *}$ & $(-20.34)^{* * *}$ & $(-14.30) * * *$ \\
\hline \multirow[t]{2}{*}{ Constant } & -50580.82 & -322268.4 & 4.7477 & 7.9585 \\
\hline & $(-4.42)^{* * *}$ & $(-4.12)^{* * *}$ & $(5.53) * * *$ & $(67.68)^{* * *}$ \\
\hline $\mathrm{R}^{2}$ & 0.5176 & 0.3609 & 0.7612 & 0.8421 \\
\hline Adjusted $\mathrm{R}^{2}$ & 0.4966 & 0.3329 & 0.7508 & 0.8352 \\
\hline F-ratio & 24.57 & 12.93 & 72.99 & 122.14 \\
\hline
\end{tabular}

$* * *, * *, *=$ significant at $1 \%, 5 \%$ and $10 \%$ respectively. 


\subsection{Effect of Price Variation on the Welfare of Fresh Tomato Consumers}

The effect of price variation on the welfare (expenditure consumption) of fresh tomato consumers is shown in equation (1)

$\mathrm{PV}=4.7747-1.07 \mathrm{CWF}+\mathrm{ei}$

$(5.53)^{*}(8.74)^{*}$

Where

$\mathrm{PV}=$ price variation

$\mathrm{CWF}=$ consumer welfare

ei= error term

Equation (1) indicates that price variation exerts negative and significant $(\mathrm{p}<0.05)$ effect on consumers welfare through consumption expenditure and the level of patronage. This implies that a unit increase in the price of fresh tomato is associated with more than proportionate fall in the quantity of fresh tomato purchased and consumed by households.

\section{Discussion and Conclusion}

\subsection{Discussion}

The price variation with major markets as measured by coefficient of variation is $16 \%$. This implies that price is relatively homogeneous. Price variation was compared among minor markets using coefficient of variation. The result shows $35 \%$ price variation among themselves. The buyer who lacks bargaining power will buy the product at higher cost. The result also revealed that price difference can occur between minor markets due to increase in number of available buyers compared to available product of fresh tomato.

This result of significant price variation between minor and major markets of fresh tomato, was expected because as the marketers transport the fresh tomato from the major markets to the minor markets the prices will vary as a result of additional cost of place value added incurred. Price of fresh tomato at the major markets plays a significant role in the determination of the quantity of tomato available at the minor markets. There was no movement of tomatoes from the minor markets to the major markets. The product flows from major market to minor markets because the product came from the Northern parts of Nigeria to the major markets then from the major markets it flows to the minor markets. This is unlike other products such as yam, maize, sweet potatoes that flow from minor markets (rural) through the wholesalers to the major markets (whether offseason or peak season of fresh tomato).

The significant price seasonal price variation implies that during the peak season the fresh tomato marketers will purchase more of the produce at a cheaper rate as against the off-season when prices of fresh tomato might have gone high due to scarcity, to high selling price to maximize profit at the detriment of consumers of fresh tomato. The result was expected because it is in accordance with the law of demand and supply.

The increase in price due to transportation cost of fresh tomato will affect the consumers' welfare because the required quantity of tomato for the household would not be purchased. The consumer is forced to reduce the quantity of tomato purchased and consumed. The result is in agreement with Ebong (2000) who said that marketing of tomato in Nigeria is affected by numerous problems which adds to transportation inconveniences, storage and labour cost. This supports Grema et al. (2015) finding that wholesalers travel far and wide to procure the fresh tomato. Therefore, they have to contend with rising transport fares. Transportation cost was found to constitute large portion of marketing margin in Africa (Ojo et al. 2016) The implication is that transportation cost is an important determinant of the price of pepper in Lagos markets. Inadequate marketing services such as packaging and handling represent major obstacles that face marketing activities (Altoum 2008).

The closer the market the lesser the transportation charges, reduced transaction costs and reduction of other marketing cost. According to Moti (2007) market choices are perfectly related to the distance to market. Therefore, the probability that marketers prefer the nearest market may be high. This is in line with Ayelech (2011) who found that distance to market caused marketed surplus of commodities. This adds to marketers transaction cost which invariably affect the consumer through increase in price of 
tomato. This is because expenses incurred by fresh tomato marketers are added to the final price of tomato sold to the ultimate consumer. This tends to reduce the purchasing power of tomato consumers and hence, quantity purchased.

The finding on the effect of price variation on fresh tomato, demonstrates that a $1 \%$ change in price of fresh tomato will translate to more than $1 \%$ decrease in consumer welfare with respect to tomato consumption. This finding could be attributed to a negative shift in the budget line/demand curve of the consumer of fresh tomato. As a result consumers are likely to consume less quantity or spend more in order to purchase and consume the same quantity of fresh tomato ceteris paribus. Adjustment of demand to price changes is a useful explanation of consumer's welfare distortion under price variation.

\subsection{Conclusion}

From the study, it can be concluded that there was inter-market price variation of fresh tomato (i.e. between major and minor markets). Inter-seasonal price variation is higher than spatial (intermarket) price variation in the study area. This implies that inter-seasonal price variation exerts more negative influence on the welfare of tomato consumers. The finding is attributed to the fact that fresh tomato is a perishable product and cannot be stored long enough from the peak season of surplus to the off season of scarcity. Fresh tomato consumers located around and close to major production centres will enjoy better welfare as against consumers located farther away. Fresh tomato consumers enjoy better price and welfare during peak season than off season. Every factor that increases marketing cost of fresh tomato will combine to increase consumer price of the produce, thereby negatively affecting the welfare of fresh tomato consumers in Nigeria. Tomato marketers should establish storage facilities through cooperative efforts. Market levies should be reduced to minimize price variation. Activities of market union should be regularized by relevant agencies to minimize price variation. Policies to encourage all-seasons fresh tomato production and marketing should be encouraged so as to stabilize fresh tomato price in Nigeria. Government should encourage the fresh tomato marketers by improving the standard of rural road networks to reduce rate of spoilage and transportation cost.

\section{Acknowledgements}

We acknowledge all the authors whose works were consulted in the process of conducting this study. We also appreciate our professional colleagues who assisted with constructive criticism of the manuscript. We thank all the reviewers that were engaged by the editor in reviewing this paper.

\section{References}

Akintunde, O. K., Akinremi, T. B., \& Nwauwa, L. O. E. (2012). Food grain marketing in Osun State, Nigeria: a study of long-run price integration. Continental Journal of Agricultural Economics, 6(1), 1-9.

Altoum, Y.A., (2008). Evaluation of the factors affecting production and marketing of tomato crop in Khartoum State. PhD Thesis, Faculty of Agriculture University of Khartoum, Sudan 162p.

Ayelech, T., (2011). Market chain analysis of fruits for Gomma Woreda, Jimma zone. Oromia National Regional State. An M.Sc thesis presented to school of graduate studies, Haramaya University 103p.

Berhanu, G., \& Hoekstra, D. (2008). Market orientation of smallholders in selected grain in Ethiopia. ILRI publication unit, Addis Ababa, Ethiopia.

Ebong, V.O. (2000). Agribusiness management in developing countries: The Nigeria perspective Uyo: Dor and Publishers.

Food and Agricultural Organization of the United Nations (FAO). (2010). FAOSTAT. Available: http://faostat.fao.org/.

Ghafoor, A., Mustafa, K., Mushtaq, K., \& Abedulla, A. (2009). Co-integration and causality: An application to major mango markets in Pakistan. Lahose Journal of Economics 14(1), 85-113. 
Gonzalez-Rivera, G., \& Helfand, SM. (2001). The extent, pattern and degree of market integration. A multivariate Approach for the Brazilian price Market. Ameri. J.of Agric.Econs.,83(3), 576586.

Grema, I.J, Gashua, AG., \& Makinta, AA. (2015). Marketing analysis of onion in Bade and Geidam local government areas of Yobe State, Nigeria. IOSR J. of Appl. Physics, 1(7), 73-78.

Haruna, U., Sani, MH., Danwanka, HA., \& Adejo, E. (2012) Economic analysis of Fresh Tomato Marketers in Bauchi Metropolis of Bauchi State, Nigeria, Nig. J. of Agr, Food and Envt. 8(3), $1-8$.

Maisamari, IY. (2002). Seasonal Price Variation. Paper presented at the tenth annual conference of the Central Bank of Nigeria's Zonal research Unit, Abuja, Nigeria, April 6th -8th, p. 16-25.

Matsane, SH., \& Oyekale, AS. (2014). Factors affecting marketing of vegetables among small scale farmers in Mahikeng local municipality, North West province, South Africa. Medit. J. of Soc. Sc.,20(5), 390-397.

Moti, J. (2007). Econometric analysis of horticultural production and marketing in central and eastern ethiopia. Ph.D Thesis Wageningen University, The Netherlands, 98p.

National Bureau of Statistics, State Information. (2015). Publications 2015 Retrieved from http://www.nigerianstat.gov.ng

National Population Commission of Nigeria. (2007). Publications retrieved from http://www.gtsnigeria.com.

Obayelu, OA., \& Alimi, GO. (2013). Rural-urban price transmission and market integration of selected horticultural crops in Oyo State, Nigeria. J. of Agric.Sc.s,195-207.

Ojo, AO., Ojo, MA., Tsado, JH., \& S, Jibrin. (2016). Spatial pricing efficiency of rice marketing in north central zone, Nigeria. Prod.Agric.and Techno.J., 12(1), 106-117.

Okpeke, MY. (2015). Assessment of marketing tomato fruits (lycopersiconesculentum). among women in Ughelli north local government area, Delta State. J.of Sc. and Multidisciplinary Res., 7, 86-95.

Olukosi, JO., Isitor, SU., \& Ode, MO. (2007). Introduction To Agricultural Marketing And Prices: Principles And Applications Living Books Serves. GU. Publications Abuja, FCT. p.142.

Sani, B., \& Hossein, AF. (2011). Determination of seasonal price variations for some food crops in Iran at Karaj zone to achieve Sustainable Agriculture. J. of Dev. and Agric. Econs., 3(1), 7-12.

Shepherd, AW., \& Ilboudo, J. (2010). Marketing of agricultural products. Food and Agriculture Organization, Rome.

Sundar, SS., \& Darren, F. (2003). Transfer costs and spatial price efficiency in the Nepalese tomato markets. Paper prepared for presentation at the American Agricultural Economics Association annual meeting. Montreal Canada July, 27-30.

Udegbe, S. E., Udegbe, M. I., Abayomi, O. T., \& Hassan, R. A. (2012). Marketing of pepper in the metropolitan region of Lagos State, Nigeria. Australian Journal of Business and Management Research, 2(1), 27. 